\title{
Attacks on South African monuments: Mediating heritage in post-conflict society
}

\begin{tabular}{|c|c|}
\hline \multicolumn{2}{|c|}{$\begin{array}{l}\text { Authors: } \\
\text { Ntsikelelo B. Breakfast }{ }^{1} \\
\text { Gavin Bradshaw }{ }^{2} \text { (0) } \\
\text { Richard Haines }{ }^{3} \text { (] }\end{array}$} \\
\hline \multicolumn{2}{|c|}{$\begin{array}{l}\text { Affiliations: } \\
{ }^{1} \text { Department of Political } \\
\text { Science, Faculty of Military } \\
\text { Science, Stellenbosch } \\
\text { University, South Africa }\end{array}$} \\
\hline \multicolumn{2}{|c|}{$\begin{array}{l}{ }^{2} \text { Department of Political and } \\
\text { Government Studies, Nelson } \\
\text { Mandela Metropolitan } \\
\text { University, South Africa }\end{array}$} \\
\hline \multicolumn{2}{|c|}{$\begin{array}{l}{ }^{3} \text { South African Cultural } \\
\text { Observatory, South Africa }\end{array}$} \\
\hline \multicolumn{2}{|c|}{$\begin{array}{l}\text { Corresponding author: } \\
\text { Ntsikelelo Breakfast, } \\
\text { nb.breakfast@m2.sun.ac.za }\end{array}$} \\
\hline \multicolumn{2}{|c|}{$\begin{array}{l}\text { Dates: } \\
\text { Received: } 18 \text { July } 2017 \\
\text { Accepted: } 16 \text { Jan. } 2018 \\
\text { Published: } 10 \text { May } 2018\end{array}$} \\
\hline \multicolumn{2}{|c|}{$\begin{array}{l}\text { How to cite this article: } \\
\text { Breakfast, N.B., Bradshaw, G. } \\
\text { \& Haines, R., 2018, 'Attacks } \\
\text { on South African } \\
\text { monuments: Mediating } \\
\text { heritage in post-conflict } \\
\text { society', Africa's Public } \\
\text { Service Delivery and } \\
\text { Performance Review 6(1), } \\
\text { a184. https://doi. } \\
\text { org/10.4102/apsdpr.v6i1.184 }\end{array}$} \\
\hline \multicolumn{2}{|c|}{$\begin{array}{l}\text { Copyright: } \\
\text { (C) 2018. The Authors. } \\
\text { Licensee: AOSIS. This v } \\
\text { is licensed under the } \\
\text { Creative Commons } \\
\text { Attribution License. }\end{array}$} \\
\hline \multicolumn{2}{|l|}{ Read online: } \\
\hline 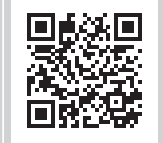 & $\begin{array}{l}\text { Scan this QR } \\
\text { code with your } \\
\text { smart phone or } \\
\text { mobile device } \\
\text { to read online. }\end{array}$ \\
\hline
\end{tabular}

Authors:

\section{Affiliations:}

Department of Political

Science, Stellenbosch

University, South Africa Mandela Metropolitan University, South Africa

${ }^{3}$ South African Cultural

Corresponding author: Ntsikelelo Breakfast,

\section{Dates:}

How to cite this article: . on South African monuments: Mediating heritage in post-conflict Service Delivery and Performance Review 6(1), a184. https://doi.

Copyright:

(c) 2018. The Authors. Lisensee: AOSIS work Creative Commons Attribution License.
The controversy surrounding the notion of national heritage and what constitutes a proper heritage in post-apartheid South Africa intersects with issues of identity and identity formation in a post-conflict society. That it impinges powerfully on social cohesion has been thrust into the spotlight in view of recent protest action related to colonial and apartheid era monuments. We have made the point elsewhere that conflict resolution in South Africa through negotiations, the National Peace Accord and the Truth and Reconciliation Commission has, at best, been partial, that it has not always been taken sufficiently seriously to engage with the fault-lines of protracted social conflict in the country. This article has employed a qualitative methodology because it is both descriptive and explorative in nature. The main aim of this article is to provide a critique on how issues of intersectionality (race, class and gender) coincide with the attacks of the monuments by university students in South Africa. This article utilises two theoretical frameworks, namely, classical Marxism and Black Consciousness, simply because both the psychological and class analysis were invoked by the student bodies to diagnose and prognose the challenges of black South Africans within the context of higher education in South Africa. The central thesis of this article is that the attacks on monuments in South African universities were instigated by a group of young people who claim to be revolutionary in thinking and are calling for transformation, free education, dismantling gender oppression and doing away with institutionalisation of racism.

\section{Introduction}

A series of attacks in 2015 on apartheid and colonial-era monuments, beginning with an attack on the statue of Cecil John Rhodes at the University of Cape Town (UCT), have occurred, seemingly out of the blue, in the South African political space. The movement to do away with the statue of Cecil John Rhodes stems ostensibly from pressure against a lack of democratic transformation in South Africa's universities, particularly at UCT, but increasingly also at other institutions. To a large extent, the pressure is justified, as some of the former white universities still do not reflect the South African demographics with respect to their staff and student profiles, or in their academic curricula. They remain very Western and white-oriented in many respects and, as with so much in the new South Africa, transformation lags seriously behind, and often occurs only in response to protest. Mamdani (1996), in his classic work titled Citizen and Subject, argues that South Africa (like other African countries) still has institutional legacies of colonialism. A case in point of institutionalisation of colonialism is the intellectual space. The ontological and epistemological assumptions of the creation of knowledge are still a reflection of Westernisation.

Although the attacks on Rhodes's statue appear to be a co-ordinated and well-considered response by UCT students to real problems in the topography of South Africa's tertiary education sector, the same cannot be said of the further series of iconoclastic activity throughout much of the country. Paint has been used to deface the statue of South Africa's first Prime Minister, General Louis Botha, outside the Parliament buildings in Cape Town, as well as that of Transvaal Republic President, Paul Kruger, in Church Square, Pretoria, in addition to a few statues in the Eastern Cape, including one in memory of horses that died in the South African war. Some of these attacks were the work of the Economic Freedom Fighters (EFF), who used the opportunity to outmanoeuvre the African National Congress (ANC), which is being portrayed as perpetuating the status quo in South Africa with regard to social and class relations.

The current discourse on historic statues represents a paradoxical situation with regard to intellectual discourse on South African campuses regarding South Africa's apartheid and colonial past. While it is important in stimulating new forms of activism and debate, the terms of such efforts are relatively limited in their scope and reference. At its most simple, it is a focus on older 
and historical vestiges of imperialism and the concomitant questioning of the continued influence of white academics and administrators within the universities. The 'pejorative singular' notion of a white academic and black academic, however, is not problematised. The complexity of the social reality that prevails in societies is not invoked. Given the increased influence of complexity theory in 21st century academic work, ${ }^{1}$ this is not an insignificant omission. Race, as a transformative category or construct, is privileged or hegemonic in this process. The class and gender and even cultural dimensions or aspects are at best accorded cursory consideration. It is these tensions and conflicts that theorists and practitioners of conflict resolution must embrace in order for scholarship to flourish. This is not to advocate a partisan approachm but rather to seek to expand intellectual exchange on such matters as part of a broader set of interventions within the economy and polity of South Africa and, for that matter, other developing and transitional states. This article makes a substantive contribution to the scholarship of social sciences on how issues of intersectionality (race, class and gender) coincide with the attacks on the monuments by university students in South Africa. The next section examines the theoretical frameworks of this article.

\section{Theoretical frameworks}

This article employs two theoretical frameworks as tools of analysis, namely, classical Marxism and Black Consciousness. Precisely, these two theoretical apparatuses were used by student activists (between 2015 and till date) in South African universities to critique the legacy of racism or colonialism and class relations in higher education. Classical Marxism is a political programme of the proletariat. Karl Marx and Engels developed the Communist Manifesto in 1848 to critique class relations in a capitalist mode of production. Their social analysis was informed by what was happening in Europe, in particular in England during that epoch. Marxism uses political economy as a method of analysis to examine the class struggle (Breakfast 2009:105, 2013:50). Marxism employs historical materialism to examine the transition between feudalism and capitalism (Engels \& Marx 1848:3-6). Marx (1867), in his seminal work titled Das Capital, introduces the concept of dialectical materialism drawing from the work of Georg Hegel.

In this regard, Marx (1867) examines the natural laws of nature by arguing that human beings are influenced by the material conditions as opposed to morality or human principles. Class contradictions are as a result of the capitalist system, owing to economic exploitation. For instance, the working class sells its labour to the ruling class; however, the income of the proletariat is not the same as its contribution, owing to surplus value. This means that the profit goes to the owners of the means of production, namely, the capitalist. Surplus value is the source of profit for the bourgeoisie class. The circulation of money in a capitalist system is caused by the exchange value. This refers to the economic exchange in the market place, between the buyer and the owner. This leads to the culture of accumulation by the capitalist class. Marx, though, spoke about primitive accumulation as a strategy of the ruling class during feudalism to amass wealth (Marx 1867). Harvey (2005:178) refers to a method of accumulation of the ruling class in this day and age known as 'accumulation by disposition'. This is a new form of accumulation by the capitalist class, whereby money is accumulated via interest rates by the financial capital. In a capitalist mode of production, social and class relations are determined by who owns what. The ruling class is in a position of power in a capitalist society because it owns the means of production and buys labour from the working class. These power relations reproduce inequality, poverty and unemployment among the working class (Marx 1867). The end of private ownership (known as socialism) is seen as a solution by Marx and Engels (Engels \& Marx 1848:32).

With regard to Black Consciousness, it is a psychological tool that is meant to liberate black people from mental slavery and inferiority complex. Black consciousness is seen to be a way of life by its proponents. It is associated with the works of Fanon and Biko, among others. Reflecting on this context, Biko (1978:30-31) argues that black consciousness is an inward-looking political philosophy; it is meant to instil black pride and dignity because black people were perceived by the colonialists and imperialists to be inferior. Fanon (1952), in his classical work Black Skin, White Masks, quotes Westermann:

\begin{abstract}
... black inferiority complex is particularly intensified among the most educated. Their wearing of European clothes, whether rags or the most-up-to date style, using European furniture and European forms of social intercourse, adorning the Native language with European expression, using bombastic phrases in speaking or writing English. They think that all this contributes to a feeling of equality with the European. (p. 25)
\end{abstract}

\section{Research objectives}

The objectives of this article are as follows:

- To provide a critique on how issues of intersectionality (race, class and gender) coincide with the attacks on the monuments by university students in South Africa.

- To explore the similarities between xenophobic episodes and the attacks on the statues.

- To examine how the conflict resolution in South Africa through Negotiations, the National Peace Accord and Truth and Reconciliation Commission in South Africa has not always been taken sufficiently seriously to engage with the fault-lines of protracted social conflict in the country.

- To critique the attacks of monuments by South African university students by employing both classical Marxism and black consciousness as tools of analysis.

\section{Research methodology}

This research follows a qualitative approach, because this article is descriptive in its design. Secondly, this article is a 
literature assessment study, guided by value judgements. Thirdly, this article is located within the context of antipositivism. This refers to the research paradigm of this article. Anti-positivism rejects the notion of objectivism and embraces subjectivism as a method of analysis in social sciences (Breakfast 2013a:135-139). The ontological and epistemological assumptions of this article are linked to the theoretical frameworks of this study that social reality is a subjective construct. The next discussion examines the notion of monuments in South Africa.

\section{On monuments}

The role of monuments needs interrogation against the background of deep-rooted social conflict - a special form of conflict, which characterises the South African situation, and upon which we will expand later. Firstly, however, we discuss the role and purposes of monuments more generally.

Monuments serve various purposes - to instil pride in past glories, the greatness of the nation and the excellence of leadership etcetera, and also to remind populations of where authority lies. This may seem relatively straightforward in a comparatively homogeneous society, but in multi-cultural societies, where identity is contested, power is shifting and insecurities run deep, questions inevitably arise. What is intended to unite often serves to divide.

Christian (2012:3) maintains that monuments '...serve a utilitarian purpose of inviting dialogue; unpacking repressed memory; re-evaluating who participated; who sacrificed; roles played by individuals and groups within the collective'. He goes on to say that monuments are the concretised manifestations or expressions of shared memories, and that these '...negotiate the meaning of that memory until it becomes historical memory'. There is, in Christian's analysis, an assumption of continuity - of an ongoing, uninterrupted accretion of collective memory, as society assimilates the formerly excluded individuals and groups into the inclusive social identity, which may be an accurate understanding of a less profoundly conflicted society than that of South Africa. He writes, for instance:

The monuments and sites of memorial can grow to accommodate additions to the historical record with collective memories of groups claiming participation and the rights of inclusion. Such additive growth only ensures the deepening of the interconnectedness of society. (Christian 2012:8-9)

In societies such as that of South Africa, however, which have experienced, or which continue to experience, protracted social conflict, a fundamental dislocation may have taken place that so overturns an existing dispensation, that a new, emergent order might totally reject the symbols of a past that is viewed as unacceptably unjust, oppressive and associated with a tarnished minority. To some extent, that would also be true of post-war Germany ${ }^{2}$ or post-Soviet Russia.

2.The telling point is often made that there are no statues of Hitler in the public spaces of present-day Germany.
The utility of monuments, in part then, is that they serve to remind us of a shared past. There is a particular view, associated with Santayana (1950), that those who forget the past are condemned to repeat it. The monuments of any country remind us not only of the glories of the past, but also the follies thereof, and the mistakes not to be repeated. But Tint (2010), writing on the impact of history and memory on intractable conflict astutely warns: 'those who do remember their past, live their past and honour their past are continuously replaying the cycles of struggle and conflict that are their legacy'. How does all of this relate to the constantly changing nature of society? We find it telling that Christian brings in the notion of the negotiation of meaning and memory above, something which clearly resonates with the conflict management field, and to which we will return in due course. The next section discusses the theorisation of race as it relates to statues.

\section{The historicity of race}

As this research has race as its centre, it is important to first examine what is meant by race and racism as social constructs and why racial tension often leads to conflict? Du Bois in his seminal work titled The Souls of Black Folk argues that one of the major problems in this day and age is the issue of race (2005:17). So what is race? Earlier biological theorist, Spencer (1971:11), argues that the development of different races is as a result of social evolution. Evans (2015:22) points out that there is scholarly evidence that the human species originated from the African continent and then moved to other parts of the world. According to him, this happened 125000 years ago and had an impact on the human race in terms of the physical characteristics of mankind.

Spencer followed a similar line of thinking with Charles Darwin's scholarship (1971:29) titled On the Origin of Species, that all different races in the world are coming from the same species. ${ }^{3}$ Suffice it to say, race is a biological construct according to the biological school of thought.

Moreover, before the social evolution theory of race, race was influenced by religion, in particular the interpretation of the Bible. At a theoretical level, the argument has been made that monogenism emanated from the biblical text that all the descendants of Adam and Eve led to the degeneration of mankind, with black people having been cursed far worse than white people because of their physical appearance (Evans 2015:64). Banton (1998:17) argues that human beings evolved into different races after God instructed men to leave the 'Garden of Eden'. The human race has evolved into different races owing to its settlement in different geographical areas. A case in point is the creation of the apartheid system in 1948. It was premised on the false hermitic misrepresentation of the Bible, that God gave orders for one race to rule over the other race(s).

3.For further discussion, see also the classical work of Darwin (1874), titled The Descent of Man and Selection in Relation to Sex. 
More often than not, the concept race is invoked to denote the physical characteristics of a person. It is worth noting that scholars on race relations do acknowledge different biological features of people in society. However, some do not attach any cultural, political, religious, ideological and social meaning to that. This implies that the biological physical characteristics of human beings are meaningless according to the critics of the evolution theory (Banton 1998:196; Greenstein 2015:149; Hughes \& Kroehler 2005:217). This means that race is a social construct as opposed to be a biological construct. In this context, race is seen to be a product of social conditions. Kammeyer, Ritzer and Yetman (1994:281) state that power relations in race politics has to do with the ability of one race to realise its political, social, cultural and economic interests. In other words, one race has the ability to subjugate the other race. The expression of racism where power is located is known as 'whiteness'.

According to Steyn (2001: xxiv), 'whiteness' is an ideological construct that is meant to maintain white privileges in society. 'Whiteness' is also premised on the racial superiority complex of white people over other racial groups. Said (1978), in his classical work titled Orientalism, provides a critique of 'whiteness' and Western racism as it relates to the oppressed (black people). This is despite the fact that the work of Said focusses on the Middle East. Similarly, the concept of orientalism is applicable to all parts of the world where 'black bodies' are found. Orientalism refers to how the West looks down on black people and their culture (Said 1972:4-5). Over and above, Said (1972:5) points out that the relationship between black people and white people is underpinned by power relations owing to the hegemony of Western culture. This line of thinking demonstrates how black people are subjugated by white people and Western cultural imperialism. 'Whiteness' presupposes that the Western worldview is superior to the African paradigm. Interestingly, white supremacy has been challenged by student activists in South Africa, before and after 1994; this is reflected upon below and is linked to political identity in the form of intersectionality among young people. The following discussion examines youth politics in South Africa.

\section{The influence of materialism, globalisation and the West on South Africa's youth}

The rationale behind this section is to examine the reasons for political disengagement among young people in the so-called new South Africa. This article does concede that the recent political activism via the \#FeesMustFall and \#RhodesMustFall movements has been the antithesis of political apathy. However, these political activities of student politics between 2015 and 2017 have been limited to institutions of higher learning. Again, this section will critically lay bare some of the philosophical and theoretical weaknesses of lenses of students during the fees protests and colonial statue criticism.
It is of paramount importance to examine the historical development of youth politics when one seeks to understand the current problem that South Africa experiences in relation to the recent monument attacks. The 'political assault' on the \#RhodesMustFall movement, among other things, was spearheaded by young people, namely, UCT student activists. Both the psychological and class analysis were invoked by the student political activists to diagnose and prognose the challenges of black people within the context of higher education in South Africa. Black people in this article refer to all those who were historically oppressed by apartheid and colonialism. Moreover, it also includes people of mixed race and Asians, because they too were economically marginalised by discrimination laws of colonialism and apartheid. Again, according to Biko (1978:22-54), black people are those who saw themselves as a 'political unity' for their psychological and economic emancipation. Similarly, the theoretical apparatus utilised by the student activists during the \#FeesMustFall and \#RhodesMustFall movements were reminiscent of the role of young people during the epoch of apartheid.

More specifically, the ideological framework employed as a tool of analysis by the first generation of young leaders in the early 1940s (through the ANC Youth League) was Pan Africanism. The philosophical tradition of Pan Africanism is associated with the ideas of Marcus Garvey, Du Bois, Kwame Nkrumah and Robert Sobukwe that 'Africa for Africa'. Pan Africanism also advocates that the African continent belongs to the majority of people who live there (Breakfast 2009:81). The Pan Africanist movement acknowledges the role slavery, colonialism and apartheid have played in the oppression of the African people. Of late, proponents of Pan Africanism have been talking about neo-colonialism which refers to the economic exploitation of African countries through trade relations mainly (Nkrumah 1980).

Fanon, in his seminal work titled The Wretched of the Earth, argued that every generation has a responsibility to take a stand against social injustice (1963:145). The youth of the 1970s used Fanon's work to critique the apartheid government in South Africa. Black consciousness motivated the youth of 1976 to engage in mass action. The black consciousness Movement (BCM) rose to prominence in the late 1960s owing to the absence of two prominent liberation movements, namely, the ANC and the Pan Africanist Congress (PAC) in the South African political landscape. When both the ANC and PAC were banned in 1960 by the Nationalist government, a 'political void' was created in black townships. Against this backdrop, black consciousness came into the political terrain to fill in the gap that was left by both the ANC and PAC. Interestingly, the BCM was a 'political vehicle' driven by young people in their twenties in institutions of higher learning and township schools.

The youth of 1976 were inspired by, among others, the youth of the 1940s, who established the African National Congress Youth League (ANCYL), and whose leaders included Nelson Mandela, Oliver Tambo, Robert Sobukwe, Walter Sisulu and 
Anton Lembede. Thirty-six years ago, on June 16 1976, thousands of Soweto high school learners took to the streets to protest against the government's intention to impose Afrikaans as a medium of instruction in black schools. After 1976, many young people left the country to go into exile. As their aim was to take South Africa by means of an armed struggle, they received military training. Some of them died in exile and others were hanged in South Africa (Breakfast 2013a:10; Breakfast, Bradshaw \& Haines 2017:2; Deegan 2005:53; Vagenas 1986:34).

Following the unbanning of the national liberation movements and the release of political prisoners in February 1990, the entire South African political landscape changed significantly. Subsequently, youth political organisations started to vigorously attack the media, scholars and others who so easily wrote off the black youth as a 'lost generation' (Everatt 2000:2). The expression 'lost generation' in this context refers to young people in the new South Africa who are often politically apathetic, materialistic and involved in crime and alcohol abuse. According to Seekings (1996:108), the concept of 'lost generation' came into the picture in South African 'body politic' during the era of political transition to democracy. He goes on to say that youth political apathy in South Africa was part of the global economic phenomenon. It is worth noting that the fall of the Soviet Union has had an impact on the depoliticisation of young people via the neo-liberal paradigm, effectively promoting the culture of individualism and 'conspicuous consumption'.

Levin (2005:90) writes that South Africa's third democratic general election in 2004 has been documented and analysed by both the media and academic intellectuals. He argues that the most interesting aspect of the 2004 election was the failure of the young people to vote, and he points out that voter registration among the country's youth was very low in the 2004 national election. It is worth noting that voter turnout among the youth in the 2014 South African national elections was not impressive at all. This is despite the fact that the Independent Electoral Commission (IEC) had gone out of its way to encourage young people in different sectors of society to vote.

The advent of democracy in post-apartheid South Africa has fundamentally changed the political landscape. Firstly, at this juncture, young people in South Africa have rights; they can decide whether or not to participate in politics, unlike in the past where the political environment required people to be active. Secondly, some aspects of globalisation have influenced the thinking of many young people in South Africa in relation to politics. Young people in the postapartheid era are influenced by American music and foreign clothing labels and they enjoy spending money lavishly. The youth in the new South Africa has a neo-liberal outlook to life imbued with individualism and rampant materialism (Breakfast 2009:75; Everatt 2005:89). One of the most important aspects of Marxism relates to its rejection of an individualist-based explanation of behaviour, in favour of a more collective approach, grounded in the tensions between broad economic classes, and specifically of the attempt to provide a scientific explanation for inequality, poverty and unemployment (Breakfast 2013a:50).

In approaching the subject, there is a need to understand the complex interplay of race, class, gender and the imperial project. The conceptual suggestiveness of Marxian political economic extraction is of distinct use, or otherwise, the debate is grounded in a structured set of factors, overdetermined by the construction of race. According to Engels and Marx (1848:1), 'the history of all hitherto existing society is the history of class struggle'. This implies that social conflict is caused by the different interests of the working and ruling classes. The recent attacks on monuments in South Africa, in particular in institutions of higher learning is caused among other things by a 'class struggle' along racial lines. For instance, black students in historically white institutions, namely, UCT, Wits, Rhodes, University of KwaZulu-Natal (UKZN), University of Pretoria and Stellenbosch University, hold the view that in as much the academic standards of these universities are high, they (the black students) do not yet have a sense of ownership of those universities, precisely because they happen to be part of the black working class. Therefore, their values do not form part of the mainstream thinking of historically white institutions (Breakfast et al. 2017:2-8).

However, some academics (including the Vice Chancellor of UCT, Max Price) have argued on a number of occasions that the problem is not racism when it comes to the shortage of black academics but fewer black people are interested in becoming academics in South Africa. Over and above, there is a shortage of black people in South Africa with PhD degrees (Pather 2016:1-6). Jansen (2009:149) states that there is a tendency among South African universities to appoint a massive number of junior academics to be associate professors despite the fact that there have not mastered the craft of scholarship. He argues that the ANC-led government appoints black people to senior positions because of the colour of their skin, similar to what the Nationalist Party did under its rule.

The argument by both Price and Jansen is problematic on two accounts. First of all, the thesis by the two academics is an expression of denialism on institutionalisation of racism in higher education. Secondly, 'whiteness' and white privileges still give white scholars an upper hand to be considered for academic promotions, simply because 'whiteness' is still perceived by university structures of power as a symbol of excellence. This is despite the fact that some of them (white academics) are not well published or have no substantial research profile. However, this is not to deny the hard work that is displayed by some of the white academic intellectuals in manufacturing scientific knowledge. Racism is still a form of oppression that is embedded in higher education in South Africa. Omitting race in any scholastic analysis is tantamount to being intellectually dishonest. 
The attacks on monuments in South African universities were instigated by a group of young people who claim to be revolutionary in thinking and are calling for transformation, especially the appointment of black academic staff (in former white universities). Institutionalisation of racism is entrenched in the organisation culture of former white universities in South Africa. According to Bobo and Fox (2003), institutionalised racism refers to:

...a set of institutional conditions of group [of people] and an ideology of racial domination, in which the latter is characterized by a set of believes holding that the subordinate racial group is biologically or culturally inferior to the dominant racial group. (p. 319)

The dominant paradigm is still Westernisation in South African universities. Thus, the \#FeesMustFall movement has been advocating for decolonisation of the curriculum and intellectual production among other things. Fanon (1952:17) argues that what is extremely important for black people is not to understand the world but to change it for the better. He states that black people should free themselves from the mindset created by the colonial environment. Evans (2015:31) refers to what he calls 'the mythology of Afro-barbarism', which means that Africa has never contributed anything to the scientific realm, meaning that only the Western world has made a substantive contribution to the body of knowledge (Evans 2015:31-32). Even in this day and age, numerous scholars continue to hold this view that Africa has nothing good to offer in terms of scientific knowledge.

Diggs (1968:x) states that academics have abused science by engaging in a self-fulfilling prophecy to prove that white people are intellectually superior and black people are less intelligent. She goes on to say that numerous pseudoscientific studies were undertaken to re-enforce white supremacy that black people were not capable of taking rational decisions. Racial prejudice towards the African continent became extremely pervasive. Social sciences, namely, Political Science, Sociology, Anthropology and Psychology, have also been instrumental in propagating the ideological construction of white supremacy (Diggs 1968:xi). This implies that intellectual production has also been used by scholars to disseminate racist ideas in the scientific community.

Interestingly, Malema (2017:17) posits that when UCT student activists demanded that the Rhodes statue must fall, it was a reflection of black pride. He goes further to assert that when the students at the University of Pretoria and the University of the Free State demanded Afrikaans not to be a medium of communication, it was an expression of black consciousness. There is a need for contextualisation when one articulates the paradigm of black consciousness. Failure to do so will lead to a misinterpretation of what black consciousness stands for, as some have tried to project black consciousness as a racist political thought. The argument that black consciousness is racist is flawed and baseless. For instance, black consciousness is a response to all forms of oppression, in particular racial oppression. Furthermore, black consciousness does not advocate for the hatred of white counterparts. It embraces all and sundry as equal across the racial divide.

At a critical level, classical Marxism has been criticised by proponents of black consciousness such as West (2009:229 233) and Asante (1998:5) for ignoring the issue of racism in its analysis. This means that Marxism is too obsessed about class characterisation without taking into account that underdevelopment among black people was caused by institutionalised racism. For instance, colonialism and apartheid were premised on the fact that, among other things, better services had to be given to the white population, thus ensuring that black people received poor services. Black people did not receive services unequal to those of white people because the majority of them were part of the working class, but rather because they were oppressed for being black and regarded as an inferior race.

Even though apartheid and colonialism are gone, however, their impact on underdevelopment is still felt by many people because they were discriminated against on the basis of the colour of their skin. Again, the majority of black people are uneducated, without skills and are not employable because of the consequences of the apartheid policy of separate development. ${ }^{4}$ This is the kind of analysis that is lacking in the theorisation of Marxism with respect to underdevelopment. None of the Marxist theoreticians in Europe including Karl Marx have cited the issue of institutionalised racism as a cause of underdevelopment in their analysis (Breakfast 2013a:63)

Nonetheless, confining the problems of black people (psychological oppression, social relations, etc.) to black consciousness and Pan Africanism is flawed and one-sided. For instance, black people do not only suffer from psychological oppression, though they still bear the brunt of racial or psychological oppression. Among other things, the black race is also a victim of class oppression. Black people still do not own the means of production in post-apartheid South Africa. The struggles of the working class are universal, ${ }^{5}$ regardless of race.

All in all, limiting the struggles of black people to race is too reductionist in its approach in the sense that it focusses too heavily on racialisation. This implies that the employment of a psychological analysis alone to 'black bodies' is too simplistic and ignores other complexities and class contradictions in society. This does not deny the existence of racism in society. Both black consciousness and Pan Africanism also omit gender oppression in their intellectual analysis. Political philosophers such as Marcus Garvey, W.E.B. du Bois, Fanon and Biko did not offer any critique on gender relations. There is no philosophical and theoretical

4.This does not mean that all the black people who are unemployed at the moment are not educated.

5.See also the work of Lenin (1901) on this matter. 
analysis that is provided by black consciousness and Pan Africanism on the oppression of women by men. These two philosophical traditions are less critical about the exploitation of women. The absence of gender analysis by some proponents of black consciousness and Pan Africanism has created some political internal fighting within the \#FeesMustFall movement. Strong advocates of feminism hold a view that racial and class analysis should not leave out the issue of patriarchy. According to Crenshaw (2017), the multiple forms of oppression, namely, race, gender and class should be understood as intersectionality. Intersectionality signifies how race, class and gender overlap as different forms of social injustice (Crenshaw 2017).

The young people in historically white institutions have argued that young people in South Africa need to honour their political heroes by participating in politics. According to these students, if young people today do not participate in politics it would mean that they do not acknowledge the contribution and sacrifices made by the youth of 1976. They hold the view that young people in post-apartheid South Africa need to remember that the democracy they enjoy did not come cheaply; a price was paid for it and people had laid down their lives for freedom (Deegan 2005:53; Vagenas 1986:34). According to Castells (2010:1), issues of political identity are shaped by neo-liberalisation and information technology in modern society. He goes to say that political identity is also associated with dominant social institutions or trends and is internalised by a number of social actors. It is worth noting that young people on a global scale have been influenced by the new social trends, namely, social media. They spend a huge amount of time in the social media space as opposed to engaging in traditional political spaces of mobilisation. However, it needs to be stressed that social media can also be used as a tool of political mobilisation, as was witnessed during the Arab Spring. The following section of the article will examine South Africa's deep-rooted conflict.

\section{The protracted nature of conflict in South Africa}

South Africa has long been held out as an example of protracted or deep-rooted social conflict. ${ }^{6}$ This has frequently been used as an explanation for the stubborn nature of that conflict, along with similar conflicts such as that in the Middle East and in Northern Ireland. The South African conflict resisted attempts at intervention, until the so-called 'miracle' of the 1994 settlement. According to theorists such as Azar (1990) and Burton (1997), protracted social conflicts display elements of frustrated human needs, very often involving needs in the psychological, rather than the economic, realm, relating to aspects such as identity, security and control (Burton 1984). In addition, there would be a 'communal' element such as competing collective actors, based on ethnic or religious affiliation (Azar 1990). Governments in countries

6.The terms deep-rooted social conflict, protracted social conflict and intractable are all used in the conflict management literature by scholars, such as J.W. Burton, L. Kriesberg and Edward Azar, to denote conflicts that are long-standing and prove resistant to attempts to resolve them. beset by protracted social conflict often exacerbate the conflict by their skewed delivery of services, based on such ethnic affiliation. The final element of protracted social conflict, according to Azar's model, is the heavy dependence on outside actors, which makes resolution of conflict difficult. Even a cursory analysis of the South African situation yields support for its characterisation as a protracted social conflict.

Burton and Dukes (1990) have made the point that protractedness means that such a conflict is resistant to what they call the 'traditional' approaches to conflict intervention, especially the twin, related techniques of negotiation and mediation. The problem with these approaches is that they essentially require parties to compromise their fundamental human needs satisfactions. Burton has painstakingly made the argument for the 'necessitous' nature of human beings, indicating that in large measure, we are needs-driven, and therefore not simply prepared to negotiate away our human needs satisfactions. At any rate, we do not feel compelled to honour agreements that deny basic human needs. Basic human needs, famously, according to Burton $(1984,1997)$, are 'not for trading'. This is used as explanation for the numerous failed attempts at resolving conflicts in the Middle East, Sri Lanka and Northern Ireland, among others. Burton has, however, provided alternative approaches to dealing with such conflict, beginning with his work in the 1960s on 'controlled communication', through his development of the 'problem-solving workshop' as intervention instrument, and finally his notion of 'conflict prevention' (Bradshaw 2008b; Burton 1984, 1997).

\section{The South African settlement and the rainbow nation}

The South African settlement of 1994 has correctly been lauded as a miracle, which gave rise to the so-called 'rainbow nation'. In many respects, the South African transition to democracy is unique, with an incumbent, minority government, and the former oppressor negotiating itself out of power. The transition involved not only the use of negotiations among the major parties to the South African conflict but also, additionally, the use of specific 'second track diplomacy' interventions during the prenegotiations phase, which simulate a number of Burton's prescribed conflict resolution approaches. In addition, South Africa developed its own conflict management system in the shape of its National Peace Accord, to manage potentially harmful conflict behaviour during its transitional phase. Finally, the South African Leadership established its own highly regarded Truth and Reconciliation Commission to deal with continuing after-effects of the struggle against apartheid and the human rights abuses perpetrated then (Bradshaw 2008a).

The South African negotiations took place in three distinct phases. The first phase, known as the Convention for a Democratic South Africa (CODESA), began in October 1991, and continued, in five working groups, to March 1992. 
This was followed by CODESA II, which began two months behind schedule, on 15 May, 1992. Some important issues could not be agreed upon, however, and CODESA II was declared a failure by its own Management Committee, as levels of violence in the country increased (Bradshaw 2008b:196-200), and negotiations stalled. The third phase, labelled the Multi-Party Negotiating Forum, began on 01 April 1993, and although 26 different parties participated, important issues were increasingly negotiated by the National Party and the ANC alone, through the mechanism of 'sufficient consensus'. There was an air of undue haste about this final phase, and important, longer-term issues were sometimes left off the table, to be dealt with by a future, democratic government. Considerations regarding the future economy, land reform and heritage were among those issues. Meintjies (2013) has similarly made the point:

But CODESA did nothing to rearrange economic power. It was silent on the need for ownership changes in major corporations. It sent no message about the need to reverse injustice in land ownership. (p. 1)

In the declaration of intent that underpinned CODESA, it was stated that the emergent constitution should 'inter alia' '...acknowledge the diversity of languages, cultures and religions of the people of South Africa' (CODESA Declaration of Intent 1991). This principle of inclusiveness also found its way into the Interim Constitution which formed the basis of the new state. The working groups at CODESA were understandably concentrated on the conditions for free political activity, the constitution-making process, interim government, the timelines for completion and the incorporation of the former homelands (O'Malley Archives, Report on CODESA Agreements).

Herwitz (2012) states pithily that:

Apartheid ended in 1991, but its monuments were still standing. And so the question for the new government, brought to power in the first democratic elections in South African history (1994), was: What to do with them? (p. 5)

\section{Monuments and deep-rooted social conflict}

Monuments are cultural expressions and are associated with identity, and in any particular society, they will be seen as reflective of a particular era and set of authority relationships. While some see them as positive reflections, others will see them in a negative light. This is well understood. The treatments of monuments, therefore, have to be dealt with very sensitively, if that treatment is going to enhance social cohesion rather than damage it. The argument has been made elsewhere that South Africa is a country in deep-rooted social conflict. The notion that South Africa is somehow a 'postconflict' society is therefore misguided. It is precisely those deep-rooted aspects of the South African conflict which demand that the value-based and human-needs-based aspects of South Africa's conflict receive the full attention of all of the important parties, if they are not to occasion a deterioration in our social cohesion.
South Africa has repeatedly been portrayed in the conflict literature as a country in protracted social conflict. The conflict meets the four basic criteria for protracted social conflict set out by Azar (Bradshaw 2007), as discussed above. It has an important communal aspect, has been fuelled by frustrated human needs, is characterised by skewed governmental provision of services and has significant dependencies in its relationships with other countries. The frustration of basic human needs, particularly the needs for identity, security and participation have long been at the very core of the South African experience, and have contributed to its resistance to easy settlement. It is exactly the tensions around identity that impinge on the controversy surrounding the country's monuments. The new South Africa represents a dramatic departure from the old. The country has shifted from being a minority-ruled racial oligarchy, to a democracy under one of the world's most progressive constitutions. The values of the new South Africa stand diametrically opposed to those of the old.

The monuments of the old South Africa reflect the values and victories of the oppressor and the colonialist, and as such seem an anachronism to many in the new, particularly as they struggle with extreme inequality, great poverty, a lack of access to land, poor service delivery, violent policing and many other ills. The question may therefore be asked whether the old monuments do not still testify to a current and unbeloved country. For the majority, has enough really changed? Do the monuments not bear witness to this lack of change?

South Africa has constructed many monuments and places of memorial since 1994. There are numerous statues to Nelson Mandela and other struggle heroes, the Apartheid Museum, Constitution Square and Robben Island, among others. The message of most of these is clearly the triumph of democracy over racial oppression. But many cities, understandably, are still dominated by the structures lauding a previous, darker reality. Christian (2012) makes the point that:

\footnotetext{
...nearly everything that human beings construct or create is done so to satisfy physical, psychological or spiritual needs of the individual and the group. The needs that drive the construction of monuments and sites of memorial are among the most complex and are often deeply imbedded in the individual and collective subconscious. (p. 1)
}

The new monuments are often exemplary; they are contextualised, and facilitate learning and an understanding of the country's past. They do not shy away from the brutality of that past, and include prisons such as that at Robben Island, and the so-called 'factory of death', the gallows of Pretoria Central Prison, which saw more than 3500 hangings before 1994. Quite obviously the intention of these monuments is not to celebrate capital punishment, or the convict labour of Robben Island; it is to place it into context and display the narrative of struggle and overcoming. Equally, the old monuments are part of an 
historical context - a part of the ultimately victorious but still continuing journey of the 'rainbow nation'. And that is how they should be seen.

Some South Africans will still identify with aspects of the 'old' monuments. Not necessarily with oppression, but perhaps with the perceived courage of Voortrekker pioneers overcoming the hardships of a frontier life, or a particular historical identity. The ultimate point is that there are many stories that have been woven to constitute the new South Africa.

Attempts to deface, remove or destroy monuments accomplish little, and may well threaten the needs of some South Africans to express their identities, and tell their stories. That will impact negatively on the possibility of social cohesion in the country, if not carefully handled.

\section{The xenophobic attacks}

One of the repetitive forms of mass violence in South Africa is the episodic incidences of xenophobia, which occur in many of the mainly urban centres in the country. There is a similarity in the xenophobic and iconoclastic outbreaks, in that both relate primarily to a widespread intolerance of difference, which has been identified by scholars, such as Gibson (2002) and Gibson and Gouws (2003), as being problematic for the new South Africa. The point has been made that government has a role to play here, in emphasising the need for tolerance. Instead, as in the case of recent xenophobic episodes, leadership is often identified as fanning the flames of intolerance, as a result of seemingly thoughtless comments, such as those attributed to the Zulu King.

Burton has made the point $(1984,1997)$ that human needs satisfactions work differently to other sources of conflict. They are at once more difficult to resolve via negotiated compromises but easier to resolve if approached sensitively, through a problem-solving framework, as they do not obey the law of zero-sum gains. The issue of monuments illustrates the point beautifully. Two different individuals can have their own monuments, which do not necessarily detract from each other. My monuments can, and should, be contextualised by yours, to collectively tell the larger story of the becoming of South Africa. Moving beyond the ideas of Burton, and the basic human needs explanations, this is an insight which also resonates with mediation literature, especially that on 'narrative mediation' (Winslade \& Monk 2000), that seeks to tell a new story, acceptable to all sides in a conflict.

Mediation in a broader sense, rather than a simple intervention, needs to be considered here. Burton called for the intervention by what he called 'scholar practitioners', especially those that understood the social sciences. In a sense, this is what we are calling for, the involvement or intervention by the community of scholars in South Africa, who need to take up the debate on matters of basic human needs, and deeply-held values, including issues such as identity, land, etc., in order to facilitate national dialogues around these outstanding, deep-rooted problems.

The irony of the protests against the statues is that the original driving force was essentially middle class in its origins and aspirations rather than working class. While the EFF have subsequently joined the protest, this was a reactive and instrumental move, responding to the unfolding of events. The apparent, seeming lack of involvement of the EFF in heading up some such protests may well indicate the essentially middle class sensibilities of the leading actors in the grouping.

Working class and unemployed popular classes have more immediate and material considerations. A major concern is that of employment or more likely, the lack and/or loss of employment. When actual and/or perceived threats to employment and a sense of place and security are felt, then the 'folk devils' (Cohen 2002), in this case the job-seeking foreigner and the shop owner, are highlighted.

\section{Articulating memory within a deeply conflicted, 'post-conflict' society}

The monuments issue in South Africa threatens to disrupt what social cohesion exists. There are ways to deal with it. The product of South Africa's negotiated settlement of 1994 stresses inclusiveness, and the rights of each to their own beliefs. This should therefore be the touchstone for an approach going forward. Inclusiveness is also one of the central pillars of sound conflict management, more generally. Because monuments are important, and speak to the identity needs of South Africans, they must be approached with care. As Burton (1984:140) has pointed out, the issue of identity and heritage is not a zero-sum issue, except notably, in a despotic system. In a 'new' state, identity must be negotiated; it must be developed, inclusively. There is a role here for the conflict management community, to assist in the mediation of such negotiated outcomes, if they are called upon to do so.

Part of the intervention is to look to understand the complexities and contradictions of colonialism (in its various forms) and to grasp how differing societies and economies have confronted and in some cases managed to find distinct value in the encounters. In South Africa in particular, it would seem, colonialism is in many respects the 'unexplored other', rather than a series of entwined sets of experiences, discourses, forms of production and even nation building. In addition, as Warren (1980) stresses, the relationship between imperialism and the nature and trajectories of capitalism in African and developing economies more generally need to be grasped. Of course, even these linkages are contested areas within and without contemporary Marxism and new dependency writings. Nevertheless, without looking for meaning and synthesis, colonialism is an often underinterrogated process. The ways in which India and South Korea have looked to profit from colonial rule (English and Japanese, respectively) is the kind of debate that needs to 
be stimulated in South African settings. Indeed, the structures and myths and narratives of British Rule in India has been the stuff of movies, cultural tourism, etc. Indians have come in part to own and profit from the colonial experience.

With these kinds of imperatives the emphasis is more on the presence of statues and other artefacts deemed colonial for their generation of interest. Indeed, the very controversial nature of such artefacts could be a marketing opportunity and stimulus to tourism. Other African countries have essentially kept the structures, images and material aspects of their colonial past. The point has been made by Robert Mugabe himself that Zimbabwe maintains Rhodes's grave, for instance. By having the memory of colonialism present, in fact provides a legitimation for post-colonial and post-independence regimes. It is also salutary to seek to place the debates about colonial statues and their longterm influence on current processes of transformation of academic institutions and public life more generally, within the past and present complexities of South African society. Mediating the complexity of social reality is central to new forms of intervention. Such interventions also need to take cognizance of half-forgotten histories as well as the persistence of long-run trends, the longe durée, as Fernand Braudel puts it (Haines 2014).

Simplistic constructions of the West and the South do not reflect changing demographies and geographies (Pike, Rodriquez-Pose \& Tomaney 2011). There is scope too for recapturing the more progressive elements of the enlightenment project. As Chibber (2013) has recently argued, it is possible to affirm the possibility of a universalising theory and even related norms and values, without resorting to Eurocentricism or reductionism.

\section{The role of universities}

The role of the university in the 21st century still remains a contested terrain. This is because of the philosophical and ideological ideas associated with the mode of operation of universities on a global scale. For instance, both Marx (1867) and Gramsci (1971) argue that universities are part of the superstructure. The notion of a superstructure denotes that the ideological framework of the ruling class. Again, the superstructure refers to the political, scientific, legal and media institutions which are supporting the capitalist mode of production. The superstructure is directly linked to the base, namely, the economic structure of the capitalist system (Gramsci 1971; Marx 1867). Engels and Marx (1848) posit that knowledge production in a capitalist society is ideological driven. This implies that scientific knowledge is not valuefree. It is a 'political project' pursued by the owners of the means of production. Over and above, the idea of objectivism in intellectual spaces in a fallacy, precisely because science is embedded within the capitalist mode of production.

The ongoing outbreaks of protest at South African universities which have coalesced around the banner of \#FeesMustFall reflect far more than just the expense of attending university. They reflect a basket of concerns relating to social inequality, the commodification of education and a corporatist style of leadership that continues to alienate the majority of South African students and makes university education increasingly inaccessible and alienating to the majority of students. According to Jansen (2016), speaking of the vicechancellors of South African universities:

In a crisis you listen in order to understand deeply what the problem really is. The rush to solutions, however logical, should recognise that in times of crisis students want to vent, to unleash what they could not do during peace times.... When as leaders we lack the credibility to speak into the noise, we are not heard and then coercive force takes over when persuasion should have been sufficient. (p. 8)

At universities, where the value of debate should be cherished, it is also important that the complexity of the issue be foregrounded, and understood. The teaching of history and politics should take place in a sensitive way, to not only stress the importance of the negotiated settlement but also to decolonise the curriculum. There is an important place for conflict management and conflict resolution in this process; and process is always important in the management of conflict. The debate must be properly facilitated and mediated. As Burton stipulated, the role of the 'scholar practitioner', the social scientist with his understanding of human behaviour, should be carefully cultivated and placed at the centre of the process (Burton 1984:161-166). And this needs to occur through the process of 'prevention'. Burton and Dukes (1990) explain their notion of 'prevention' as follows:

Provention...is a decision making process in which the future is analysed and anticipated, and as a result policy decisions are taken to remove the sources of likely disputes and conflicts. Were consideration for the future given priority, civilizations would be threatened only by an inadequate understanding of human relations and systems operations. But civilizations have yet to discover the representative political system that gives priority to the future. Provention, a study of conflict avoidance, would be at the core of such a political philosophy. (p. 161)

The implication is that government needs to play an important role in leading this process. It needs to place the public debate on the table, and sustain it. Government cannot simply be reactive. What is important is for the deconstruction of the relevant discourses of transformation so that there is greater clarity and more specific scope for conflict practitioners. It is also important to consider the space(s) within which they operate, and their contribution to the strengthening of civil society and democratic values and practices.

Presuming that conflict practitioners do come from differing ideological backgrounds, it is important that a meta-position with regard to the facilitation of dialogue and debate be established. This can be played within and without the university space, and more generally within the terrain and operations and activities of civil society. The longer view as opposed to short termism is important. 
However, the assumption that universities are central sites for discussing and resolving the issues of transformation, and perpetuation of the grand narrative of freedom and diversity of speech, is also to ignore the changes within universities since the late 20th century. Habermas's concern at the growing hegemony of the economy and state imperatives in conditioning the workings of contemporary universities, and their functionalist tendencies in the later 20th century, have been reinforced in recent years by a growing scholarly literature.

\section{Conclusion}

The line of argument of this article is that the attacks on monuments in South African universities were instigated by a group of young people who claim to be revolutionary in thinking and are calling for transformation, free education, dismantling gender oppression and doing away with institutionalisation of racism. The controversy surrounding the notion of national heritage and what constitutes a proper heritage in post-apartheid South Africa intersects with issues of identity (race, class and gender) and identity formation in a post-conflict society.

It is a truth, long recognised and widely articulated by the community of conflict resolution practitioners, that social conflict itself holds great potential for positive change. In South Africa to date, this community has been relatively silent on the issue of the statues conflict, whether out of a sense of respect for the parties, or as a result, perhaps of their own 'privilege of office'.

The field of conflict management can add great value to South African society at this time, by providing policy advice to government, as well as specific, targeted interventions, such as relationship-building exercises, problem-solving workshops or structured facilitated value-sharing dialogues. Large-scale training of leadership and strategic sectors in conflict management skills would likely have positive effects and give rise to better decision-making across the country. A variety of these roles might be combined in a conflict management system approach, such as applied in South Africa's National Peace Accord, in the early 1990s.

\section{Acknowledgements Competing interests}

The authors declare that they have no financial or personal relationships which may have inappropriately influenced them in writing this article.

\section{Authors' contributions}

This scholarly work was performed by all the three authors. The bulk of the work was done by the primary author, N.B.B., namely, the following sections: Theoretical Frameworks, Research objectives, Research methodology, the historicity of race and the influence of the West. The remaining sections were written by other authors jointly.

\section{References}

Asante, M.K., 1998, The Afrocentric idea, Temple University Press, Philadelphia, PA. Azar, E., 1990, The management of protracted social conflict, Dartmouth Publishing Company, Aldershot.

Banton, M., 1998, Racial theories, 2nd edn., Cambridge University, London.

Biko, S., 1978, I write what I like, Picador Africa, Johannesburg.

Bobo, L.D. \& Fox, C., 2003, 'Race and racism and discrimination: Bridging problems, methods, and theory in social psychological research', Social Psychological Quarterly 66(4), 319-332.

Bradshaw, G.J., 2007, 'An evaluation of the application of specific conflict management mechanisms in the South African transition to democracy, 1985-2004: A conflict resolution perspective', Unpublished doctoral thesis, Nelson Mandela Metropolitan University, Port Elizabeth.

Bradshaw, G.J., 2008a, Conflict management for South African students: Theory and application, New Voices Publishing, Cape Town.

Bradshaw, G.J., 2008b, 'Social cohesion in a post-conflict context: A case study of South Africa twelve years on', International Social Science Journal 192, 183-195.

Breakfast, N., Bradshaw, G. \& Haines, R., 2017, 'Political Apathy Amongst Students: A case study of Nelson Mandela Metropolitan University', Africa's Public Service Delivery and Performance Review 5(1), 1-8. https://doi.org/10.4102/apsdpr. Delivery
v5i1.172

Breakfast, N.B., 2009, 'An investigation into political apathy amongst students', A case study of Nelson Mandela Metropolitan University', Unpublished Master of Arts dissertation (political studies, Nelson Mandela Metropolitan University, Port dissertation

Breakfast, N.B., 2013a, 'Market triumphalism and the South African State: A case study of local government in the Eastern Cape', Unpublished PhD thesis, Nelson Mandela Metropolitan University, Port Elizabeth.

Burton, J.W., 1984, Global conflict; The domestic sources of international crisis, Wheatsheaf Books, Brighton.

Burton, J.W., 1997, Violence explained: The sources of conflict, violence and crime, and their prevention, Manchester University Press, Manchester.

Burton, J.W. \& Dukes, F., 1990, Conflict: Practices in management, settlement and resolution, The Macmillan Press Ltd., London.

Byrne, D., 1998, Complexity theory and the social sciences: An introduction, Routledge, London.

Castells, M., 2010, The power of identity, in The information age: Economy, society and culture, vol. 2, 2nd edn., Blackwell, West Sussex.

Chibber, V., 2013, Postcolonial theory and the specter of capital, Verso Books, London.

Christian, P.J., 2012, 'Memory monuments and conflict', in P.J. Christian (ed.), History memory and conflict, Winter/Spring 2012, pp 1-5, Nova Southeastern University, Lauderdale, FL.

Clarke, S., 2015, 'South Africa's failure to arrest Omar al-Bashir is betrayal of Mandela's ideals', The Guardian, 24 June, pp. 7-8.

CODESA Declaration of Intent, 1991, African National Congress, viewed 29 June 2015, from www.accord.org.za/ajcr-issues/building-trust-and-playing-hardball

Cohen, S., 2002, Folk devils and moral panics, Routledge, London.

Crenshaw, K.W., 2017, On intesectionality: Essential writings, The New Press, New York.

Darwin, 1874, titled The Descent of Man and Selection in Relation to Sex. Jjohn Murray, New York

Deegan, H., 2005, The politics of the New South Africa: Apartheid and after, Pearson Longman, Cape Town.

Diggs, I., 1968, 'Introduction to the transaction edition', in W.E.B. Du Bois (ed.), Dusk of dawn, pp. 1-5, Transaction Publishers, New Brunswick.

Du Bois, W.E.B., 2005, The souls of black folk, Simon and Schuster, Inc., New York.

Engels, F. \& Marx, K., 1848, Manifesto of the Communist Party, Political Pamphlet, Bookmarks, London.

Evans, G., 2014, Black brain, white brain: Is intelligence skin deep? Jonathan Ball Publishers, Cape Town.

Everatt, D., 2000, 'The dead decade? Youth in post-apartheid South Africa', Development Update 3(2), 5-17.

Everatt, D., 2005, Growing up tough: A national survey of South African youth, Ravan Press, Johannesburg.

Fanon, F., 1952, Black skin, white masks, 3rd edn., Pluto Press, London.

Fanon, F., 1963, The wretched of the earth, MacGibbon \& Kee, London.

Fleming, T. (ed.), 2006, The university and democracy: Habermas, adult learning and the learning society, New York, p. 77, viewed 26 March 2017, from http://eprints. maynoothuniversity.ie/1055/1/UnivandDemTFleming.pdf

Gibson, J.L., 2004, Overcoming apartheid: Can truth reconcile a divided nation? HSRC Press, Cape Town.

Gibson, J.L. \& Gouws, A., 2003, Overcoming intolerance in South Africa: Experiments in democratic persuasion, Cambridge University Press, Cambridge.

Gramsci, A., 1971, Selections from the prison notebooks, transl. Q. Hoare \& G.N. Smith, Lawrence and Wishart Limited, London. 
Greenstein, R., 2015, 'Race', in P. Stewart \& J. Zaaiman (eds.), Sociology: A concise South African Introduction, pp 149-150, Jata and Company (Pty) Ltd. Cape Town.

Haines, R.J., 2014, 'The poverty of progress? The case for development history', paper presented at Development Studies Association, University of London, London, UK, 23-27 June.

Harvey, D., 2005, A brief history of neoliberalism, Oxford University Press, Oxford.

Herwitz, D., 2012, Monument, ruin and redress in South African Heritage, Action Heritage, Columbia University Press, New York.

Hughes, M. \& Kroehler, C., 2005, Sociology, McGraw-Hill, New York.

Jansen, D., 2009, 'Intellectuals, the state and universities in South Africa', in L. Diken \& W. Gumede (eds.), The poverty of ideas: South African democracy and the retreat of intellectuals, pp 143-168, Jacana Media (Pty) Ltd., Johannesburg.

Jansen, J., 2016, 'Leading in a crisis', Journal for Development and Leadership $5(1), 8$

Kammeyer, C.W., Ritzer, G. \& Yetman, N., 1994, Sociology: Experiencing changing societies, 6 th edn., Allyn and Bacon, London.

Lenin, V., 1901, What is to be done?, Bookmarks, London.

Levin, M., 2005, 'Opting out of organized politics: Youth and the election', Development Update 3(2), 25-42.

Malema, J., 2017, 'Biko knew that we are either alive and proud, or we are dead', Sunday Times, 10 September, p. 17.

Mamdani, M., 1996, Citizen and subject, David Philip, Cape Town.

Marx, K., 1867, Das capital, vol. 1, Bookmarks, London.

Meintjies, F., 2013, The TRC and CODESA failed South Africa: Its time we reflected on this, South African Civil Society information Service, viewed 29 June 2015, from www.tandfonline.com/doi/pdf/10.1080/02582473.2017.1295646
Nkrumah, K., 1980, Neo-colonialism, the last stage of imperialism, Peace and Socialism Publishers, Prague.

O'Malley, P., n.d., The O'Malley archives, Report on CODESA agreements, viewed 29 June 2015, from https://www.nelsonmandela.org/omalley/index.php/site/q/ 031v02039/04v0204lv02046/05Iv02047/06lv02048.htm

Pather, R., 2016, 'UCT appointments escalates transformation row', Mail and Guardian, pp. 1-6, viewed 30 August 2017, from https://mg.co.za/article/201603-03-uct-appointments-escalated-transformation-row

Pike, A., Rodriquez-Pose, A. \& Tomaney, J. (eds.), 2011, Handbook of local and regional development, Routledge, London.

Said, E., 1972, Orientalism, Penguin Books, London.

Santayana, G., 1950, The Wisdom of George Santayana, Kindle, Rome.

Seekings, J., 1996, 'The "Lost Generation": South Africa's youth problem' in the early-1990s', Transformation 29(1), 103-125.

Spencer, H., 1971, Structure, function and evolution, Michael Joseph, Ltd., London.

Steyn, M., 2001, Whiteness just isn't what it used to be, State University of New York Press, New York.

Tint, B., 2010, 'History, memory and intractable conflict', Conflict Resolution Quarterly 27(3), 1-19. https://doi.org/10.1002/crq.258

Vagenas, C., 1986, 'An analysis of black consciousness in South Africa according to the theoretical criteria of a revolutionary philosophy', Unpublished Master's dissertation in Political Science, University of Port Elizabeth, Port Elizabeth.

Warren, W., 1980, Imperialism, pioneer of capitalism, Verso, London.

West, C., 2009, Keeping faith: Philosophy and race in America, Routledge Classics, New York.

Winslade, J. \& Monk, G., 2000, Narrative mediation: A new approach to conflict resolution, Jossey Bass, San Francisco, CA. 